\title{
THE UNIVERSITY OF OXFORD EXPEDITION TO PERU, 196I
}

$\mathrm{T}$

HE University of Oxford Expedition to Peru, 1961, has recently returned to the United. Kingdom after completing approximately three months field work in the Central Andean Region south of Huancayo. The investigated area covered. 600 sq. miles between latitudes $12^{\circ} 25^{\prime}$ and $12^{\circ} 50^{\prime} \mathrm{S}$., and longitude $75^{\circ} 15^{\prime}$ and $75^{\circ} 30^{\prime}$ W., at altitudes from 13,000 to $18,000 \mathrm{ft}$. O.D. Six scientists completed an integrated study which concentrated on the geological and botanical features of the country.

No previous work had been done on the geology of the area, although the region was adjacent to country mapped by Dr. J. V. Harrison of the Department of Geology and Mineralogy, Oxford. R. C. Herrera constructed an initial geological map on the scale $1: 50,000$. This work was augmented by detailed. stratigraphical sections of the Mesozoic and Tertiary, and by systematic collection of fossils, especially from the Cretaceous limestones. A small number of volcanic and acid intrusive specimens were collected for Prof. B. Giletti of Brown University, in conjunction with a programme of age determination of Andean rocks. The results of the investigation will be used by Dr. J. J. Wilson, of Lima, in his work on the Mesozoic history of the Andean Geosyncline.

The botanical work, carried out by J. R. Lloyd and J. K. Marshall, was divided into five parts. First, a collection was made of the flowering plants, ferns and bryophytes of the whole area. Concomitantly, a map and general survey of the plant formations in the region were completed. Thirdly, the quadrat method was used for a more intensive exam. ination of samples from the formations of all districts. Completeness and precision were given to this phase by the detailed study of all the communities of a selected $10 \mathrm{sq}$. mile plot. Material comparable with the recently discovered ferm-allay, Stylites, was found to be widespread in the Distichia bogs, and an autecological investigation was made of this and other genera. Finally, analysis of the changes of day and night temperature of four different flowering plant. genera was carried out. The botanists were accompanied for a short time by Dr. O. Tovard, a Peruvian taxonomist, who aided in collecting and general survey.

S. R. S. Walker carried out work on the various soils, the majority of which were skeletal lithosols with a marked absence of horizons. His work was closely linked with the ecological programme of the botanists, and the samples will be analysed at the Department of Botany, Carnbridge.

A 1 : 50,000 map of the north-eastern part of the area was compiled by the surveyor, M. R. Bewsher; this supplemented the smaller-scale published maps; Stadia methods were used to map at $1: 5,000$ a limited area of particular interest to the botanists. In addition, Bewsher recorded continuous meteorological observations at six stations.

M. J. Troughton undertook a geographical description of the study area, and in particular of the Ayhuicha Valley centred on the village of San José de Acobambilla. This is an isolated and particularly self-sufficient peasant community, and he was fortunate in being able to carry out the investigation during the 'faena' or collective community work period. At this time the men are recalled to the village from work among the herds on the puna grazing areas, thus presenting a good opportunity of observing the various activities of such a population.

Throughout the Expedition, great use was made of animal transport-mainly peck mules, which, in spite of their temperament, were ideally suited to the rough mountainous terrain. The mules, the extreme hospitality of the loeal Indians, and a working lknowledge of Spanish were found to be great aids to exploration in the Andes of Peru.
R. C. Herrera

\section{ELECTRON MICROSCOPY IN THE UNITED STATES}

\begin{abstract}
THE nineteenth annual meeting of the Electron Microscope Society of America was held at the Pittsburgh Hilton Hotel, Pittsburgh, Pennsylvania, during August 23-26. The Local Arrangements Committee, headed by Dr. Robert V. Rice, is to be especially commended for the arrangement and success of this meeting, which brought together more than 706 active workers in electron microscopy from 24 American States, Canada, Australia, Great Britain, Belgium, Germany and Japan. It was the largest meeting in the history of the Society. There were ten general sessions of contributed papers, five in the biological fields, five in non-biological areas; in addition, a special session on techniques and three symposia were features of the programme. Nineteen scientific exhibits were presented and twenty-one commercial exhibitors participated in the meeting. Some 180 authors contributed papers on the technique and applications of the electron microscope to work in biology, chemistry, medicine, cancer, metallurgy, electron diffraction and related fields.
\end{abstract}

A limited number of programme abstracts are still available from Dr. A. R. Taylor, Parke, Davis and Co.,
Detroit, Michigan. One hundred and three new members of the Society were elected, making the total membership 1,040 .

In the symposium on "The Contribution of Electron Microscopy to Polymer Morphology", organized by Dr. R. G. Scott (Pioneering Research Division, DuPont Experimental Station, Wilmington 98, Delaware), seven experts in this field discussed X-ray diffraction applied to polymers, spherulites, electron diffraction applied to single crystals, morphology of polymers, fibre microscopy and electron diffraction applied to synthetic fibres. Arrangements for this symposium were planned over a period of two years and summarized the new phases of technology and applications of electron microscopy in the field of polymer science.

Dr. Rubin Borasky (Electron Microscope Laboratory, Graduate College, University of Illinois, Urbana, Illinois) arranged and directed the symposium on "Ultrastrueture of Protein Fibers-Collagen, Muscle, and Keratin". The papers on physical, chemical and mechanical properties of protein fibres in muscle and keratin summarized the recent con. 
tributions to the science of fibre structure, especially collagen.

The symposium on "The Fine Structure of Viruses" arranged by Dr A. F. Howatson (Medical Biophysics Department, University of Toronto, Toronto 5, Ontario) was especially noteworthy in that the presentation of papers on recent advances in fine structure, animal virus structure, electron microscopy of nucleic acids and proteins, structures of bacteriophages and their variations, and work on the fine structure of foot-and-mouth disease virus brought together in a very logical sequence the information on the recent improvements in the techniques of replication, shadow-casting, thin sectioning and "negative contrast" staining and their application and interrelationships in obtaining new information on the structure of viruses both in situ and isolated.

\section{Fifth International Congress for Electron Microscopy}

Arrangements for the Fifth International Congress for Electron Microscopy to be held in Philadelphia during August 29-September 5, 1962, were announced. at the meeting.
The Electron Microscope Society of America will be the host for the International Federation of Electron Microscope Societies at this Congress to be held, coincidently, on the twentieth anniversary of the Electron Microscope Society of America. Efforts are being made to have the Congress include the most significant developments since the last Congress in Berlin in 1958. The general theme will emphasize new and unique contributions of electron microscopy toward the advancement of science. In addition to contributed papers, the programme is being organized to include special papers by invited speakers which will set the theme of each session. In the interest of the earliest possible dissemination of the new material to be presented at the Congress, the Committee has completed arrangements for each active member at the Congress to receive the bound copy of the scientific papers at the time of registration. This will contain an abbreviated paper, including some micrographs or illustrations, for each scientific contribution presented at the Congress.

Further information can be obtained from the Secretary, Fifth International Congress for Electron Microscopy, 7701 Burholme Avenue, Philadelphia 11, Pennsylvania.
A. R. TAYLOR

\section{THERMIONIC CONVERSION OF HEAT TO ELECTRICITY}

\begin{abstract}
A SYMPOSIUM on the thermionic generation of electricity was held at Bankside House, London, on May 11. It was organized by the Central Electricity Generating Board and attended by workers in the field of thermionic generation from a number of public and private concerns in Britain.

An opening address by Dr. K. H. Spring, of the Research and Development Department of the Central Electricity Generating Board, was followed by a paper from Mr. R. V. Harrowell, also of the Board, and Dr. J. Myatt (Atomic Energy Research Establishment, Harwell) on the efficiency and power of a diode generator. This paper examined the simplified expression for efficiency:
\end{abstract}

$$
\eta=\frac{\varphi_{c}-\varphi_{A}}{\varphi_{c}+P_{L} / I_{A}}
$$

where $\varphi_{c}$ and $\varphi_{A}$ are cathode and anode work functions, $P_{L}$ is the power loss and $I_{A}$ is the anode current. When $\eta$ is plotted against $\varphi_{c}$, the resulting humped curve is asymptotic to zero efficiency as $\varphi_{c}$ is increased indefinitely; and for $\varphi_{c}=\varphi_{A}, \eta=0$. It was pointed out that emphasis is seldom laid on the fact that this efficiency curve is valid only for a matched load at each value of $\varphi_{c}$ : it is then true that $\eta=0$ at $\varphi_{c}=$ $\varphi_{A}$. But it is quite possible, under non-matched conditions, to have a high efficiency even when $\varphi_{c}=$ $\varphi_{A}$, and this, or an intermediate state, may be desirable in certain circumstances. More important is the fact that, under matched conditions, maximum efficiency may sometimes be sacrificed for an increase in power; in this case $\varphi_{c}$ will be less than its value at maximum efficiency.

A low anode work-function is important for the realization of high efficiency. The effective workfunction of a metal anode in cæsium vapour depends on the cæsium coverage of the surface. A value below both the figure for clean metal and the bulk eæsium work-function can be achieved with a correct balance between the anode temperature and the saturated cæsium temperature: a value of $1 \cdot 1 \mathrm{~V}$. has been quoted.

A study of the work-functions of anodes opposite oxide cathodes has been made by Dr. B. J. Hopkins (University of Southampton). The work-function of a clean nickel anode $(\sim 4.7 \mathrm{~V}$.) fell to less than $2.5 \mathrm{~V}$. when the cathode was in the most active condition. Dr. Hopkins considers that barium oxide evaporates from the cathode in the molecular form and is deposited on the anode. Three methods of measurement were used : two depend on the determination of the contact potential difference from retarding field curves; the other uses the contact potential difference obtained by the Kelvin method. If the contact potential difference between the cathode and $a$ known reference surface is also measured, then the anode work-function can be found by eliminating the cathode work-function from the two expressions; alternatively, the cathode work-function can be measured from a Richardson plot, although this would give a less trustworthy result.

Mr. D. C. Gore (Central Electricity Generating Board) read a paper entitled "The Thermionic Diode in Large-Scale Power Production from Fossil Fuels". This dealt with the diode as a thermodynamic topping device in a conventional boiler, using the upper part of the available temperature-range, which is not usable in a steam cycle. The mechanical arrangement would be for the diodes, in cylindrical form, to envelop the boiler tubes; the outer, cylindrical cathodes would be heated by the furnace gases. If a diode efficiency of 20 per cent could be attained and the efficiency of the conventional plant were 35 per cent, the total plant efficiency would be raised to 45 per cent by the introduction of diode 'toppers' passing three-quarters of the available heat. Any saving in fuel costs would probably be considerably offset by the relatively short life of the diodes, but Mr. Gore believes that if the very difficult problems of materials can be solved there are reasonable prospects for reducing generating costs. Some of the problems 